\title{
Progres of the Public Procurement System in Albania and in the European Union
}

\author{
Emalita Dobra \\ The first instance of Tirana District Court (procurement specialist) \\ emalitarama@hotmail.com
}

(0692602020)

\section{Abstract}

A proper estimation of the value of the public contracts is of major importance of the contracting authority. First, value of contracts govers the regime of rules under which the proceedings will be conducted. Second the decision of the contracting authority concerning the application of specific procurement procedure depends whether the value of contract is below or above specific threshold. For multi year contracts or contracts with renewal option, the contracting Authority must provide clauses for the revision of prices in accordance with published official inflation. In case of goods the contracts through renting or leasing of these, the estimated value of the public contract shall be based on the monthly rent or fee multiplied by the number of months the contract will last. The contracting Authority is responsible for comparing the above mentioned elements with a cost analyses of the goods, services or works. European Union rules provided in Article 9 of the directive 2004/18/EC of the European Parliament and of the council of 31 March 2004 on the coordination of procedures for the award of public works, supply and services and in contain also more detailed rules concerning methods of estimation of contract value which should be applied in specific case. The priciple of the transparency of public procurement requires that all potential contractors have the same chances to compete for contracts being offeres by public administration. (Keywords; public contracts, procurement, goods, proceedings contracting Authority, etc. )

\section{Introduction}

Public procurement is a process performed by the Contracting Authorities (CA), which select the Economic Operators (EO) through a public competition, to enter into public contracts for the provision of goods, services or works (construction), against payment from public funds ${ }^{1}$. There lies a public purpose and a public task behind the public procurement, which the contracting authorities provide for by means of the procurement. The construction of a school is necessary for the education of pupils. The background to procurement can be cultural policy, commercial policy etc. The construction of a power station can be necessary for the maintaining of power on the electric grid. More detailed considerations of its construction, size, technology, location etc., can also involve issues such as the pollution of the environment, the competitiveness of the national economy, safety, national security and so on ${ }^{2}$. This is a process conducted by the state administration to serve directly or indirectly the citizens, who are taxpayers at the same time. In other words, through this process a state authority "delegates" to a private entrepreneurship the right to perform activities mainly of a technical character (non policy-making), on behalf and on account of the state authority, such as for example, the service of cleaning the city, construction of rural or urban roads, etc. ${ }^{3}$ Such "delegation" is based on a bilateral contract, for the awarding of which the state authority should follow the rules of public procurement.

\section{1 Role of public procurement}

If we visualized the public procurement process, we would imagine a chain composed by the need for a good, service or work (directly for the Contracting Authority and/or indirectly for the citizens), a source of financing (public funds, i. e. income created by different types of payments from citizens), the administrator of such need and its implementer (Contracting Authority) and the direct or indirect beneficiary of the product (citizens). The "public" or "government" procurement refers to the situation, in which it is the government (whether central or local), or some public body that purchases items from the market. Those purchases are made with a view to fulfilling the tasks of government in providing public services. Procurement is, therefore, also an "acquisition for public consumption", a statement, which neatly discloses the public interest in procurement ${ }^{4}$. Such characteristic of public procurement is reflected in its two essential elements; the "public 
need" and the "public fund". The "public" character makes the procurement process highly sensitive and naturally raises the need and the necessity for the special regulation of this process. Also, the need for special rules on the award of public contracts is based on the recognition that states, in contrast to commercial undertakings, are not disciplined by market forces when carrying out procurements. Selection of a certain economic operator, without considering optimization of price and quality, at the end of a procurement procedure, could result in costs for the budget of the state authority performing the procurement. However, in no case it bears the same risks and financial costs as a private undertaking would bear at the same conditions. A private undertaking can risk even bankruptcy in such situations, while a state authority never has this cost.

1 Article 3/1 of Law no. 9643, dated 20. 11. 2006 "On Public Procurement", as amended (here and after refered as PPL).

2S. T. Poulsen, P. S. Jakobsen and S. E. Kalsmose-Hjelmborg, "EU Public Procurement Law; The Public Sector Directive, The Utilities Directive, 2nd Edition", DJØF Publishing, Copenhagen 2012, pg. 26.

3 S. T. Poulsen, P. S. Jakobsen and S. E. Kalsmose-Hjelmborg, "EU Public Procurement Law; The Public Sector Directive, The Utilities Directive, 2nd Edition", DJøF Publishing, Copenhagen 2012, pg. 27.

4 P. Trepte "Regulating Procurement- understanding the ends and means of public procurement regulation", Oxford University Press Inc., New York, 2004 (reprinted in 2006), pg. 27.

Often, indeed in the majority of the cases (frequently as a result of internal budgetary, administrative or audit regulations), the different stages of the procurement cycles are carried out by different people5. All these three stages should be included under the "umbrella" of the procurement process, because there is a close connection and a strong impact of these stages to one another. This means that in practice the three stages need to be closely integrated and regarded as separate phases of a single cohesive "cycle". It also needs to be understood that there is a significant connection between the regulatory measures that apply at the second stage and the first and third phases of the process - and that in certain cases the regulatory provisions that we consider will have a direct impact on the first and second stages ${ }^{6}$.

Besides the three stages of the public procurement process, as prescribed above, another division might be introduced as well, in the reference to these stages; stages before and after the conclusion of the contracts. Such concept does consider the steps in the procurement cycle up to and including the publication of the contract as "before conclusion", and steps that are taken after the contract is "concluded". 6 This implies that the two initial stages described above, which prepare and direct the procurement process, stand before the

\section{2. The economic aspects of the public procurement system}

Procurement regulation has been developed largely by societies, which rely on concepts based on welfare economics in the market economy and is currently being adopted in societies, which are embracing a market economy. The development of procurement regulations within a market economy implies that its purpose is in some way an instrument of the pursuit of economic welfare. In a market economy, economic welfare is achieved, in part by pursuing the objective of economic or "allocative" efficiency. This, in turns, gives rise to further considerations. First, regulation can be seen as an attempt to correct market and institutional failures in order to achieve the goal of economic efficiency. Secondly, this goal may be seen as insufficient in itself to achieve economic welfare because it is based on the assumption that optimal economic welfare will result from the perfect functioning of the free market and the achievement of allocative efficiency. But economic "welfare" may, however, be seen as something more than pure allocative efficiency. Thirdly, economic welfare may be formulated with the intention of achieving specific economic, social and political objectives, which will have an impact on the formulation of those instruments of policy employed to achieve economic efficiency. On the other hand, the public procurement process aims the management of public funds. Looking for the "best value for money" in public (and private) procurement, while keeping under control the process management costs, requires several important decisions. The issue whether centralization or decentralization is more appropriate, usually rises up when a certain organization or structure has reached a certain granditude and /or geographical expansion.

\Synergies (product of economy of scale, by avoiding duplication of efforts/work, through reduction of legal challenges); The more standardized the product/service, the bigger the advantage of contracting authorities to aggregate the request, 
as economic operators have the possibilities to make use of the economy of scale, by operating this way with a lower cost per unit.

5. The same regulation is applied also in the Albanian system; the three stages should be implemented from different people, to avoid the potential situations of conflict of interests. See for example articles 57-58 of the Decision of Council of Ministers No. 914, date 29. 12. 2014 "On approval of the public procurement rules".

6. See S. Arrowsmith "Public Procurement: Basic Concepts and the Coverage of Procurement Rules", Public Procurement Regulation-an Introduction, pg. 1, Available on-line at http://www.nottingham.ac. k/pprg/documentsarchive/asialinkmaterials/publicprocurementregulationIntroduction. pdf. Retrieved on, 20. 12. 2014.

\section{3 Components of public procurement, scope of application and exclusions}

To create the conditions for a procurement procedure, there should exist at the same time the following four elements:

1 The Contracting Authority (CA);

2 The Public Fund (state budget) available;

3 The need of the Contracting Authority for a public work, good or service;

4 The economic operators.

\section{3. 1. Contracting authority}

In the perspective of a public procurement process, a contracting authority is the one which run the process, aiming at awarding a public contract for supplies, services, or public works. The modern state employs a wide variety of institutional forms to carry out its functions; and this may make it difficult and uncertain to establish an appropriate boundary for rules that apply to "public bodies" but not to the "private" ones, including defining the general scope of administrative/public bodies for states that adopt a general distinction between the administrative/public law and private law.

Nevertheless, once a body falls within the definition of a 'contracting authority', all of its purchases of goods, works and services will be subject to the procedural requirements, even if these purchases are made for the purposes of tasks that are not, or even mostly not, in the general interest ${ }^{7}$.

Once covered by the procurement regulations (the procurement Directive, or a national procurement law, such as the Albanian case), the authority is covered for all purchases within the definition of the given regulation.

Anyway, especially in the case of a body governed by public law, the status of a contracting authority can change over time as a result of a change of its functions or a change in its legal status. The financing of the contracting authority may also change over time. These all have an effect on the inclusion of the body within the definition of the procurement rules (a Directive, or a national law, in case of Albania), and therefore it is not possible to say, once and for all, whether a body is covered or not covered by these rules ${ }^{8}$.

The applicable rules on public procurement, generally, provide for the definition of the "contracting authority". So, for example, the Albanian public procurement law, provides in article 3, point 14 that the term 'Contracting authorities' (in the public sector) means all those entities subject to the PPL for the execution of their public contracts. Namely, the following:

a. Constitutional institutions, other central institutions, independent central institutions and local governing units,

b. Any bodies:

(i) Established for the specific purpose of meeting needs in the general interest, not having an industrial or commercial character; 
(ii) Having legal personality; and

(iii) Financed, for the most part, by the State, regional or local authorities, or other public bodies; or subject to management supervision by those bodies; or having an administrative, managerial or supervisory board, more than half of whose members are appointed by the State, regional or local authorities, or by other public bodies;

7 See Case C-44/96 Mannesmann Anlagenbau Austria AG and Others v Strohal Rotationsdruck GmbH ('Mannesmann') (1998) ECR I-73, paras 30-35.

8 See Case C-470/99 Universale -Bau AG, Bietergemeinschaft: 1) Hinteregger \& Söhne Bauges mbH Salzburg, 2) ÖSTÜSTETTIN Hoch-und Tiefbau GmbH v Entsorgungsbetriebe Simmering GbmH ('Univesale - Bau') [2002] ECR I-11617.

\section{3. 1. 1 Central and joint purchasing}

Public purchasers have recognized that they can benefit from economies of scale by buying their requirements in bulk. Even where the procurement needs of a single procuring contracting authority are relatively modest in respect of a given product or service, the combined needs of a number of such government purchasers may be significant. Government departments operating in similar sectors or in neighboring locations have often found it beneficial to group together jointly to purchase specific items. This is most likely to be the case of products used daily, where the various purchasers do not have any requirements that are specific to the contracting authority or differential technical requirements61. A central purchasing body is a 'Contracting authority', which 'acquires supplies and/or services intended for contracting authorities', or 'awards public contracts or concludes framework agreements for works, supplies or services intended for contracting authorities'?.

\section{2) Legal personality}

The existence of a legal personality is generally the clearest distinction between bodies that form part of the state, regional or local authorities and those that are considered to be bodies governed by public law ${ }^{10}$. Most government ministries, departments and divisions do not have a separate legal personality. If a separate body is created as a company or enterprise, then it will have a legal personality that is separate from the state and it is likely to be seen as a body governed by public law if the other two conditions are also met. It does not matter whether the body in question is subject to public or private law, the onlyissue is whether it has a legal personality ${ }^{11}$.

\section{3) Dependency on the state}

This condition is used primarily to determine the degree of dependency of the body on the state. This dependency may, alternatively, befinancial, - managerial, or - Supervisory. This condition is satisfied where only one of these three criteria is met.

\section{Economic Operators}

To make a public procurement procedure happen, two main stakeholders (parties) should be acting; a public buyer named as the contracting authority, on one side and a private provider, named as the economic operator, on the other side. The Albanian public procurement law does provide for a definition of the "economic operator' concept, which is as follows: 'Contractor', 'supplier' and 'service provider' means any natural or legal person or public entity or group of such persons and/or bodies, which offers on the market, respectively, the execution of works and/or a work, products or services. An 'economic operator' shall cover equally the concepts of contractor, supplier and service provider, without any kind of distinction.

\section{5. 'Procurement' contracts}

The procurement legislation (neither the Public Sector Directive 2004/18, nor the PPL) does not give any particular definition of a 'procurement' contract, but only certain contracts, in concrete three types of contracts fall within the scope of this 
legislation referring to them as 'public works' contracts, 'public supply' contracts and 'public services' contracts. On the other hand, the new Public Sector Directive 2014/24 in its article 1(2) does provide for a new definition:

9 See Art $1 / 10$ of the Directive 2004/18/EC.

10lbid, para 2. 60 .

11See case C-283/00 Commission v Spain [2003] ECR I-11697 in which EJC held that it was necessary to establish only whether or not the body concerned fulfilled the three conditions for establishing the existence of a body governed by public law and that a body's status as a body governed by private law did not constitute a criterion capable of excluding its being classified as a contracting authority for the purposes of the Directives. 'Procurement within the meaning of this Directive is the acquisition by means of a public contract of works, supplies or services by one or more contracting authorities from economic operators chosen by those contracting authorities, whether or not the works, supplies or services are intended for a public purpose'. The definition of procurement brings an additional requirement - 'acquisition'- to the definition of public contract as provided by the Directive ${ }^{12}$.

\section{1 Public works contracts}

The procurement rules do give a definition of 'public works contracts', according to which works contracts are public contracts having as their object either the execution, or both the design and execution of works or a work, or the realization, by whatever means, of a work corresponding to the requirements specified by the contracting authority. A "work" means the outcome of building or civil engineering works taken as a whole, which is sufficient of itself to fulfill an economic or technical functionlt is clearly stated by the given definition, the 'design and build' contracts also fall within this definition, as the possibility of including design works into a works contract is also foreseen. This could include for example, contracts covering the designation of a project as well as its execution.

\section{1. 1 Mixed contracts}

The public procurement legislation (both Public Sector Directive and PPL) contains provisions on how to categorize a contract containing elements of works and/or supplies and/or services. The distinctions are relevant in the case of mixed supplies and services contracts. It is an issue also in the case of works contracts that contain elements of supplies or services, given the much higher thresholds that apply to works contracts. The way in which mixed contracts are categorized depends on the subjects and types of contracts, which are mixed. On the other hand, the new Public Sector Directive 2014/24/EU, does provide in a specific article for a definition of "mixed procurement", according to which "contracts, which have as their subject two or more types of procurement (works, services or supplies) shall be awarded in accordance with the provisions applicable to the type of procurement that characterizes the main subject of the contract in question'.

\section{1. 1. a Supplies/services}

Essentially, contracts containing elements of both products and services will be treated as one or the other type of contract depending on the value represented by each element. According to PPL, 'a public contract having as its object both products and services shall be considered to be a 'public service contract' if the value of the services in question exceeds that of the products covered by the contract. Based on this definition, it is understood that where the value is equal, it will be considered as a supplies contract.

\section{1. 1. b Works/services}

In the case of works and services, the procurement rules do not provide for a value test, as above, but include a test based on the principal object of the contract, as opposed to considerations that are merely incidental to that object. As such, a public contract having as its object services and including works that are only incidental to the principal object of the contract shall be considered to be a "public service contract". 


\subsection{1c Works/supplies}

12 R. Caranta "Mapping the margins of EU public contracts law: covered, mixed, excluded and special contracts", François Lichère, Roberto Caranta and Steen Treumer (eds. ) "Modernizing Public Procurement. The New Directive"; 1. Edition, Djøf Publishing, Copenhagen 2014, pg 69.

As it is clearly stated, the Albanian procurement rules, as in the case of mixed contracts with services and supplies, analyzed here above, even in the case of mixed contracts with works and supplies, will use the 'value test' to name the contract. On the other hand, under the Public Sector Directive, 'a public contract having as its object the supply of products and which also covers, as an incidental matter, siting and installation operations shall be considered to be a 'public supply contract'. For example, in the case of the purchase of a crane to be installed on a dockside, the object of the contract is the supply of the crane and not the works required to site it, even if those works are considerable. According to the Directive, this 'principal object' test, which mirrors the way in which works and services contracts are to be distinguished, would appear to apply even if the value of siting or installation services is greater than the value of the supplies itself, since it is a test based on the object of the contract and not the 'value-based test' applied to distinguish between supplies and services ${ }^{13}$.

\section{2. 5. 1. $b$ Contracts requiring secrecy measures}

The Directives do not apply to public contracts (i) that are declared secret, or (ii) the execution of which must be accompanied by special security measures in accordance with the laws, regulations or administrative provisions in force in the Member State concerned, or (iii) when the protection of the essential interests of that state's security so requires. However, these exemptions would not be automatic but would need, if challenged, to be properly justified. In a case involving the prohibition against the unlicensed importation of narcotic drugs, an argument was put forward to the effect that the provisions of the Directives could be excluded on the basis of the above discussed exemption. The Court stated that a tenderer's ability to implement proper security measures could be taken into account as a criterion for the award of a contract.

\section{New law on public procurement and its approximation process}

Considering the engagement related to public procurement in SAA, Albania drafted in 2006 a project of law approximating Directive 2004/18/EC "On coordination of public procurement procedures for works, goods and services". The new law on public procurement, oriented this time by the respective EU legislation, changed totally the public procurement system in Albania.

Law no. 9643/2006 "On public procurement" was approved by the Albanian Parliament on 20 November 2006 and entered in force on 01 January 2007, thus abrogating the previous law no. 7971/1995, and all secondary legislation. The new law was followed by DCM no. 1, dated 10 January 2007 "Rules of public procurement".

Guidelines and Tender Standard Documents were prepared, based on these two pieces of legislation. This new legal framework brought about essential changes in the sector. First of all, it is worth mentioning that the new law provided for a more detailed and clearer process of public procurement, starting with the issuing of the procurement order and closing the cycle with the signing of the contract, including also several provisions related to the contract execution ${ }^{14 .}$

The new law lays out very clearly the principle of equal treatment, the principle of nondiscrimination, the principle of transparency, the value for money principle and the principle of legal protection of economic operators' interests. Exclusion of direct procurement from the list of procedures, through which a public contract could be awarded, made one of the significant changes in the new law. In addition, the new law introduced the concept of the "abnormally low bid". All these issues provided for the first time in the new law reflected the provisions of the respective Directive 2004/18/EC.

13 P. Trepte "Public Procurement in the EU- a practitioner's Guide, Second Edition", published by Oxford University Press Inc., New York, 2007, pg. 238, para 4. 112.

14 Law 7971/1995 "On public procurement", was composed by 48 articles, meanwhile the new law 9643/2006 "On public procurement", was composed by 78 articles. 
Providing a partial approximation with the respective EU Directive, during the period 2007-2014 the legal framework passed through several changes and improvements, aiming to further approximation.

After observing application of the new legal framework on public procurement, on September 2007, the Parliament of Albania approved law no. 9800/2007. The law consisted in changing the conditions for using the procurement procedure of negotiation without prior publication of contract notice, thus approximating in full article 33 of the Albanian public procurement law with article 31 of Directive 2004/18/EC.

On December 2007, the Parliament of Albania approved some amendments to Law no. 9643/2006 "On public procurement", as amended. This Law No. 9855 of 26 December 2007, introduced new regulations on the procurement of electrical energy and of hydrocarbons. It introduced as well ex novo, the concept of "Framework agreement", thus creating the general framework for entering into special contracts for goods to be procured along a given timeframe.

Despite amendments introduced up to 2008 , there were still some important issues which were not aligned with the acquis. Among these the most important were related to the review system; the specific regulations for procurement in the utility sector; and a detailed and clear provision for framework agreements. That is why another amendment of Law 9463/2006 was necessary. Such an amendment was done by approval of Law no. 10170 of 22 October 2009. This law established for the first time a special instance for reviewing appeals in public procurement, entitled Public Procurement Commission, approximating the legislation to the respective EU Directive. The newly established institution took from the Public Procurement Agency the competence of reviewing appeals. For the first time, a special chapter on procurement in the utility sectors was also introduced, approximating the legislation with Directive 2004/17/EC "On coordinating the procurement procedures of entities operating in the water, energy, transport and postal services sectors" as well. A special article on framework agreement has been introduced. All the above listed amendments were another step forward to approximation with the respective EU Directives.

\section{Electronic procurement}

On October 2007, by Decision no. 659, Council of Ministers approved rules on public procurement by electronic means. This decision provides for the first time in the history of public procurement in Albania, the functional and legal requirements for implementing public procurement procedures by electronic means.

In the framework of measures towards increasing transparency and fighting corruption in the public procurement system in Albania, according to the Decision of the Council of Ministers No. 45, dated 21. 01. 2009, all public procurement procedures are performed through an e-procurement system.

The system offers a secure, efficient and transparent preparation and administration of all tender-related documents, removing unnecessary paper work249 and providing secure data flow throughout the entire process 15 . All the tender documents, from the contract notice to the winner notice and further more to the notice of the signed contract, are available in the electronic public procurement system.

15This position has been stated also at the Albania 2009 Progress Report of the European Commission, point 4. 1. 6 "Public Procurement" according to which "...Legislation was approved in January 2009 introducing the obligation for contracting authorities to use the electronic procurement. Contracting authorities have also to publish all procurement notices and tender dossiers on the website of the Public Procurement Agency (PPA). This has improved access to information and reduced procedural costs. The PPA provided advice and support to overcome the initial technical problems encountered. However, there are still some exceptions to the use of electronic procedures. Efforts need to continue to extend them to all types of public procurement. Electronic procedures aim at reducing the scope for corruption although further efforts are still required in all phases of the procurement process...".

Moreover, all transactions, starting from the download of documents till the bidding by electronic means, may be done at anytime and anywhere the economic operators are.

The electronic public procurement system reduces the application time, facilitates and standardizes the process of 
Introduction with the tender conditions. Likewise, it guarantees the secrecy of offers and, at the opening time of the procedures, allows the simultaneous publication of the offers.

Moreover, the electronic system does generate reports enabling ulterior inspections, ex post monitor of procedures and reduction of the possibility of corruptive deviations. It is constructed in such a way as to maintain at all times a copy of all data and all actions performed on it. The automatic recording of transactions is done by a separate server called "Black box", which is located at a completely different place from the main server and to which, moreover, none of the EPS administrators can enter.

\section{Public procurement Directives}

To assess the context, in which the public procurement system of the European Union has been developed, it is important to have a historical overview of the public procurement Directives. This will enable us to study the purpose/purposes of the procurement system in the EU and understand the extent such objectives have evolved since their beginnings.

\section{1 First procurement Directives}

General programs were implemented through a number of Directives approved consequently. They were of two types; the so called Directives of Liberalization and the Directives of Coordination. Directives of Liberalization aimed the abolition of restrictive and discrimination measures. Directives of Coordination aimed at the approximation of Member States procurement legislation with the purpose of coordinating procedures of awarding public contracts in these states.

\section{1. 1 The first Directives of Coordination}

The first two directives of coordination were respectively: Directive 71/305 on public work contracts and Directive 77/62 $2^{16}$ on goods' contracts. Both directives provided more or less for the same regulations and practically there was no strong argument why works and services had to be treated separately in two different Directives, up to 2004 when both of them and Directive 92/5017 in relation to services' contracts were consolidated in a single text. Directive 71/305 was adopted following to the General Programs with the aim of coordinating the internal procedures (legislation) of the Member States for selecting winners and awarding the public work contracts. Hence, this Directive reaffirms once again the main objectives of the General Programs such as the prohibition of setting as qualification criteria the technical specification of a discriminatory effect or the setting of the objective criteria for the participation of bidders. The Directive also gives special importance to the implementation of an effective competition in public contracts' sector. The general Treaty rules on free movement entail an obligation not to discriminate in public procurement, which is an important starting point for opening up public procurement. However, this alone has long been considered insufficient to remove barriers to trade that exist in public markets: it is widely considered that positive obligations, including transparency requirements, are needed in order to achieve this ${ }^{18}$.

16 OJ 1977 L 13/1.

17 OJ 1992 L 209/1.

18 See S. Arrowsmith "Law of Public and Utilities Procurement", Volume 1, Third Edition, Sweet \& Maxwell, London 2014, para. 3-29

Directive 77/62 was adopted with the purpose of coordination of procedures for selecting the winners and awarding the goods' contracts. This directive, in addition to the requirement for creating equal conditions for competitiveness, highlights the transparency of the procurement process, aiming at a facilitated control of implementation of the above mentioned principles. The purpose of both directives was the increase of transparency of the procurement process (by publishing of tenders in all Member States of the Community), from which derived public contracts, assuring and monitoring the principle of effective competitiveness, which in its side brings equal opportunities and equal access in these contracts (by setting objective criteria for participation and prohibition of setting technical discriminatory specifications). 
These Directives also regulated two other important aspects. First, as coordination measures, they do not require establishing a common regulatory regime in the Member States. Directive 71/305 states that coordination should take place considering as much as possible the existing procedures and practices in each member state. Article 2 of both Directives clearly provides that contracting authorities, in selecting contractors should apply their internal procedures, adopted by the Directives. These directives, differently from the later Directives, did not impose the usage of defined procedures; they provided only for defined requirements, which had to be fulfilled (mainly in relation to notice/publication rules) in case of a given kind of procedure. The second important characteristic of these Directives was that they were applicable only to procurement procedures and contracts above a certain financial value. It was the case of such values considered to have impact on competitiveness and could affect the trade among Member States.

\section{1. 1 a Some of the Directive's provisions are strictly related to the fact of the state subject to them is an EU Member State and some of them are optional for Member States themselves.}

As discussed and analyzed in several situations above, some of Directive's provisions are applicable only to Member States, which is quite loyal considering the fact that Directives aim to regulate public procurement within EU. If we recall the example of the case of application of the Common Procurement Vocabulary (CPV), in Albania, this coding system might not be directly implemented and applicable in Albania, as of the date of Albania's accession to the EU, since CPV is adopted as such by means of an EU regulation.

Another example of this situation comprises implementation of the Prior Information Notice (PIN). The Albanian PPL does not foresee such an instrument. Seen in the context of the obligation and commitments undertaken with the SAA, it will not be the case of 'non-approximation' as this is optional even for Member States. On the other hand, if it will be the case that Albanian law will provide for such mechanism anyway (even though it is not obligatory), in practice it will not be possible to implement it, because it is required that the notice itself, or the fact of publication of this notice on the buyer profile, should be published in any case, by the Publications Office of the EU. As such, it seems that this mechanism is meant only for states which are directly subject to the Directive, and there is no meaning to require a non-Member State to introduce such a mechanism in its national procurement law, because the required objective will not be achieved.

8. 1. $1 \mathrm{~b}$ National context and internal factors are very important factors regarding the approximation process. Such legislative interventions, to implement the relevant Directives should go along with economic and social changes, as public procurement is not only a legal process, but it is also an economic and social process.

Another aspect which should be considered along the integration process is the entire environment where this process takes place.

The precondition for Albania in this sector is to fully approximate its legislation in a relatively short period of time, meaning that in such short period of time the Albanian public procurement system should move from a very infantile phase of some years ago toward a much consolidated phase the EU Member States are in nowadays. It is true that Albania has only to follow models which already exist in the EU, but it is also obvious that only the fully approximation of the legislation does not mean the accomplishment of the process. The final objective is to make the legislation applicable. Making the public procurement legislation applicable and realizing a fully functional procurement system in line with EU standards, does not mean only harmonization with the respective EU Directives, but it is necessary to harmonize this legislation with other legal framework in Albania. Otherwise it will not be workable.

As discussed above, internal factors are very important as well. Such legislative interventions should go along with economic and social changes, as public procurement is not only a legal process, but it is also an economic and social process. At the end of the day, PPL is a national law, and a national law will be "shaped" also by the concrete context and environment where it is applied.

8. 1. $1 \mathrm{c}$ The New Public Sector Directive aims to provide for more simplified and flexible public procurement regime. The Albanian procurement law, while considering the implementation of new directive, should consider also the internal environment especially, for that type of provision suggesting more flexibility. 
One of the main objectives of the revision of the EU public procurement regime including the new Public Procurement Directive 2014/24 has been the simplification and so-called flexibilization of the regime. Thus, this Directive provides more freedom to public purchasers to negotiate (constraints on using the competitive negotiated procedure have been relaxed, so that this procedure is available for any requirements that go beyond "off - the - shelf" purchasing). The new rules also encourage and allow preliminary market consultation between buyers and suppliers, which should facilitate better specifications, better outcomes and shorter procurement times. In the light of flexibilization of the regime, the Directive provides as well for the possibility of assessing credentials of candidates and bidders through suppliers' self-declarations, and where only the winning bidder should have to submit various certificates and documents to prove their status and also self-cleaning measures, for suppliers who have cleaned up their bad practices.

Apart for the flexible approach, generally speaking, Directive 2014/24/EU provides for mostly mandatory rules that have to be implemented by Member States. Many provisions that were optional under 2004 Directives became mandatory in accordance with the 2014 Directives.

\section{8. $1.1 \mathrm{~d} /$ The new approach proposed by the Directive on award criteria, especially regarding life-cycle costing (LCC), might be very helpful to the Albanian procurement system, but except for the necessary changes in the legal framework, two key actions should be undertaken for this purpose; the approval of a methodology based on international experience and the education of procurement officials and auditing officials in this regard.}

The Albanian procurement rules generally comply with the relevant Directive (s) rules on defining the award criteria. They provide as well for two types of award criteria; the lowest price and the most economically advantageous tender (MEAT). Even the context of applying such criteria is the same, despite the fact that Albania is not an EU member. However, there are still some differences, which reflect the environment where PPL is applied. The environment impact is clearly reflected by the fact that, in practice more than $90 \%$ of the contracting authorities use the lowest price criterion. MEAT is mandatorily used only in case of consultancy services procedures. This situation is explained by the low level of professionalism and "fear of discretion" in the public procurement system in Albania. To promote the use of MEAT, the PPL, differently from the Directive, has even provided for some conditions when CA are allowed to use the lowest price. Along the same line come also the limitations of the PPL, not providing for the possibility of expressing weightings of the criteria by providing for a range with an appropriate maximum spread, and for the possibility of indicating in the contract notice or contract documents or, in the case of a competitive dialogue, in the descriptive

document, the criteria in descending order of importance, where, in the opinion of the contracting authority, weighting is not possible for demonstrable reasons.

\section{Conclusion}

The EU Public Sector Procurement Directive(s) and Albanian Public Procurement Law have different natures and different objectives (for the time being). The Albanian PPL is a national law which aims to regulate the public procurement system in the country. The respective EU Directives are supranational laws, which aim to regulate the public procurement system within the EU, instructing Member States to implement (in whatever way is required) certain Union policies within a fixed timetable. From this different nature of both acts induces the differences in their objectives.

From its origins, one of the main objectives of the EU has been to create a common market that eliminates barriers to trade in goods and services between EU Member States. Creating a common procurement market means removing all barriers to trade arising from the procurement context. Practically the aim of the Procurement Directives is to create an internal market where there is a free movement of goods and services and effective competition for public contracts. This aim is clearly expressed at the preamble of both procurement Directives. This aim of the procurement directives to create an internal market has also been stated by the Court of Justice in several cases. On the other hand, the PPL calls for the principle of competition in those same situations as Directive does. However referring to the objective and scope of the PPL, it is obvious that the function of this principle is to support the efficiency of the procurement system and this is understandable considering the fact that PPL is a national law.

Following the final conclusions of this thesis, aiming at an effective approximation process, I will recommend as follows: 


\section{[A clear understanding of expression "full approximation" of both parties 19}

Both parties; the EU and Albania, should 'agree' on what should be understood by the expression "full approximation", in light of the integration process and to what extend the Directive's provisions should be implemented as such, in the Albanian procurement legislation. This clarification should be conducted, to avoid misinterpretations during the integration process and to avoid different expectations of both sides;

\section{[A 'transitional' approach should be followed by the EU in the integration process.}

The approach followed by the EU (through the European Commission) with non EU Member Countries, during the integration process, should not be rigid. The EU should be aware that countries like Albania, which aim to join EU, are mostly countries in transition, meaning that they are in a different state of development (economic, social and politic) compared to the countries which are already in the EU (even though there are considerable differences among them as well). In this context, it will be more realistic to have some "transitional rules" for countries which aim to join EU, then requiring them to

19 The same wording is used also by National Plan for European Integration, when providing that "In general, the obligations arising from the SAA, in the field of public procurement, are met. The regulatory framework in this area is generally compatible, but not fully approximated with the acquis. Law no. 9643, dated 20. 11. 2006, "On public procurement", as amended, is partially harmonized with the relevant directives..." See further Chapter 5 "Public Procurement", in the National Plan for European Integration 2015-2012, pg. 158-159. Available at http://www. integrimi. gov. al/al/dokumenta/dokumentestrategjike/plani-kombetar-per-integrimin-evropian\&page=1, retrieved December 20, 2014.

\section{mEducation of procurement officials and procurement auditors to release the Albanian procurement system from the "fear from discretion"}

Trainings also play an important role in capacity building of the administration in public procurement. Given the fact the public procurement process is a very dynamic process, the training of employees being responsible for carrying out of public procurement procedures should be done on a regular and continuous basis. The procurement process is well regulated and prescribed by the PPL, including the supporting documentation, which the contracting authorities are bound to follow, but the process is not designed to foster professionalism and performance oriented attitudes and practices, education of the administration (those who carry out procurement procedures and those who audit them) for being open minded is more than necessary, in order to make the system in practice as more effective as possible. Otherwise the emphases on control, sanctions and the risk of complaints will still lead to the unwillingness to introduce quality factors and to achieve the best efficiency and value for money of the procurement process.

\section{$\llbracket$ A gradual implementation of Directive's provisions into the Albanian procurement legislation}

In any case, it is recommended that the implementation of Directive provisions at issue should be done gradually, activating at the same time the appropriate mechanisms of avoiding abusive and corruptive behavior from both sides; contracting authorities and economic operators. In this gradual approach the principle of equivalence ${ }^{20}$ and the principle of effectiveness have to be taken into account.

$\llbracket$ A coherent approximation of PPL with other national legal developments and other economic and social developments

The approximation of Albanian procurement legislation with the respective EU Directives should also be conducted in coherence with the other legislation in force in the country and the needed economic and social changes.

\section{[Opening up of PPL towards flexibility, to increase the efficiency of the procurement process}

Despite all, the Albanian procurement law should be opened toward more flexibility, to increase the effectiveness of using public money. In any case this flexibility should be increased gradually, and should be accompanied by an improved integrity level of officials in charge of procurement processes. 


\section{Bibliography}

\section{Books}

G. Gruber, T. Gruber, A. Mille, M. Sachs "Public Procurement in the European Union", NWV Neuer Wissenschaftlicher Verlag, Vien, Graz 2006.

A. Semple 'A practical guide to public procurement', Oxford University Press, United Kindom, 2015.

C. H. Bovis "EU Public Procurement Law", Second Edition, Edward Elgar Publishing Limited, United Kingdom, 2012.

20The principle of equivalence means that procedural rules are not less favorable than those governing similar domestic actions. See G. Gruber "Community law and national law", Public Procurement in the European Union, NWV Neuer Wissenschaftlicher Verlag, Vien, Graz 2006, pg. 41

D. D. Dingel "Public Procurement-A Harmonization of the National Judicial Review of the Application of European Community Law", published by Kluwer Law International, Netherlands, 1999.

D. Dragos, R. Caranta (Eds), Outside the EU Procurement Directives - Inside the Treaty?, Copenhagen, Djoef Publishing, 2012.

Department of Public Administration, "100 Vjet Administratë”, No. 12, 13, 14, Botime Pegi, 2012.

E. Piselli "The scope for Excluding Providers who have Committed Criminal Offences under the EU Procurement Directive", 2000.

F. Weiss "Public Procurement in European Community Law", Athlone Press, 1993.

François Lichère, Roberto Caranta and Steen Treumer (Eds. ) "Modernizing Public Procurement. The New Directive"; 1. Edition, Djøf Publishing, Copenhagen, 2014.

G. L. Albano, K. F. Snider and K. V. Thai (Eds), "Charting a Course in Public Procurement Innovation and Knowledge Sharing", by PrAcademics Press, USA, 2013.

"Integrity in public procurement - Good practice from A to Z", OECD Publishing 2007. «CJEU Case law

Case C-7/68 Commission of the European Communities v Italy [1968] ECR 423

Case C-155/73 Giuseppe Sacchi [1974] ECR 409.

Case C-8/74 Procureur du Roi v Dassonvile [1974] ECR 837 at 852

Case C-120/78 Rewe-Zentral AG v Bundesmonopolverwaltung für Branntwein ('Cassis de Dijon') [1979] ECR 649

Case C-115/78 Knoors v Staatssecretaris voor Economische Zaken [1979] ECR 399 at 407

$\operatorname{COM}(1986) 375$

$\operatorname{COM}(1984) 717$

COM (1984) 747

COM (1998) 143 
$\operatorname{COM}(2000) 275$

COM (2000) 276

Commission interpretative communication on concessions under Community Law (2000/C 121/02)

COM (2011) 896 final, 2011/0438 (COD).

Central European Free Trade Agreement (CEFTA)

Directive 64/427 EEC Laying down detailed provisions concerning transitional measures in respect of activities of selfemployed persons in manufacturing and processing industries falling within ISIC Major Groups 23-40 (Industry and small craft industries). 